\title{
岡山・天満屋と福井・だるま屋の開業時の立地と景観 一地方都市における近代百貨店に関する研究 その 2 - \\ LOCATION AND CITYSCAPE OF THE OPENING OF TENMAYA IN OKAYAMA AND DARUMAYA IN FUKUI \\ - Study on modern department stores in regional cities Part 2-
}

野中勝 利*

Katsutoshi NONAKA

\begin{abstract}
This paper focuses on the Tenmaya department store in Okayama city and the Darumaya department store in Fukui city, describing the characteristics of the locations, the exteriors of the buildings, and the background of the surrounding cityscapes when the stores first opened for business. Tenmaya opened in a part of Okayama that had been a commercial district since the Edo period. Darumaya was established on the site of the former prefectural office across from Fukui Station. Tenmaya's display windows gave it a modern appearance, while Darumaya was housed in a low-rise building that had an accessible feel for shoppers.
\end{abstract}

Keywords : Department store, Location, Landscape, Modernization, Tenmaya, Darumaya 百貨店、立地、景観、近代化、天満屋、だるま屋

\section{1.はじめに}

本研究は、戦前に地方都市で開業した百貨店について、立地特性、 建築外観及びまち並みにおける景観から、開業時における実態を明 らかにするものである。

既稿注了では、六大都市以外の地方都市で開業した最初期の百貨 店である鹿児島の山形屋を研究対象として分析した。山形屋以降、 全国的に百貨店の開業が広がった。本稿では 1937 年の百貨店法に よって百貨店の立地や経営が一定の統制を受けるまでの間に開業し た百貨店のうち、岡山の天満屋と福井のだるま屋を研究対象とする。

各地で開業された百貨店は、経営的な問題あるいは戦災などの被 災などによって淘汰されたが、この二百貨店は、山形屋同様、戦前、 戦後そして現在まで一貫して営業されている地域の一番大店である。 現在の天満屋は、山形屋と同じく店舗に隣接してバスターミナルが あり、市民の集散拠点と一体となっている。だるま屋は、1943 年 の火災、1945 年の空襲、1948 年福井大地震により、三度焼失した。 しかし 1953 年、市民生活への多大な貢献等から、福井県知事、福 井市長及び福井商工会議所会頭から、その復旧に対する要望が出さ れるなど、地域の支持を受けている注 2。対象とした百貨店はいずれ も都市経済の重要な一翼を担い、経営の安定、市民の支持、地域密 着といった共通の土俵上にある。
また近代百貨店建築としての天満屋は 1925 年、だるま屋は 1928 年の開業であり、これらを対象とすることで地方都市での百貨店の 展開期を追うことができる。以上のような理由からこの二百貨店を 研究対象事例とした。また既稿の鹿児岛・山形屋の分析で明らかに なった結果と適宜比較対照することで、地方都市での百貨店の実態 をより明らかにすることができる。なお既稿でも指摘したように地 方都市での百貨店に関する研究の蓄積は進んでいない。

天満屋には社史等注 ${ }^{3}$ がある。だるま屋は独自に編纂した社史を 公刊していないが、創業店主がまだ現役中に、その友人である新聞 記者が店主の半生を著した文献注 ${ }^{4}$ があり、それに置き換えること ができる。それらを参考資料とし、当時の新聞、写真、地図等の一 次資料の確認と収集に努めた。両百貨店に対しても、所蔵する資料 の照会を行ったが、いずれも戦災等により当時の資料は散逸し、保 存されていない旨の回答を得た。その一方、特に福井県文書館にだ るま屋に関する資料群が保存されていることを確認した。これは西 川秀男氏から寄贈された資料群である。1928 年生まれの西川氏は 1945 年にだるま屋に入社し、役員等を経て 1994 年に退職するまで 50 年近く勤務していた注 。寄贈資料には、西川氏が取集・作成し た資料や年表、未刊行のだるま屋 20 年史の編集資料、創業から 1945 年までの年次記録などが含まれている。特に 1928 年の開店日から

\footnotetext{
* 筑波大学大学院人問総合科学研究科 准教授 $\cdot$ 博士 (工学 $)$
} 
表 1 研究対象の百貨店の経営経緯

\begin{tabular}{|c|c|c|c|c|c|}
\hline & 年 & 山形屋 & 天满屋 & だるま屋 & 犕考 \\
\hline & (前身) & 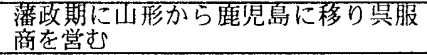 & $\begin{array}{l}\text { 潘政期に小間物屋から近服店になる } \\
\text { (郊の西大寺) }\end{array}$ & & \\
\hline 1896 & 明治 29 & & (合名会社伊原木或服店) & & \\
\hline 1901 & 奛治 34 & & (天満屋県服店と改称) & & \\
\hline 04 & 明治 37 & & & & 越 (東京、大阪) \\
\hline 07 & 明治 40 & & & & 高哥屋 (大阪) \\
\hline 08 & 明治 41 & & & & 松坂屋 (東京) \\
\hline 10 & 明治 43 & （店頭に洋風ハラベット) & & & 松坂屋 (名古屋) \\
\hline 12 & 大iE & & (岡山市に出店) & & \\
\hline 13 & 大正2 & & & & 高自屋（京都） \\
\hline 16 & 大正 5 & 洋風建築の虛舗新築・開業 & & & \\
\hline 17 & 大正 6 & 株式会社山形屋県服店（株式会社化） & & & \\
\hline 18 & 大正 7 & & 株式会社天満屋呉服店（株式会社化） & & \\
\hline 19 & 大正 8 & & & & 百不屋（東京） \\
\hline 24 & 大正 13 & & 岡山店を本店に & & \\
\hline 25 & 大正 14 & & 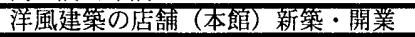 & & \\
\hline 26 & 昭和元 & & 別館增築・開業 & & \\
\hline 27 & 昭和 2 & & 西館、北館增贸・開業 & & \\
\hline 28 & 昭和 3 & & 株式会社天満屋に改称 & だるま屋・開店 (個人経営) & \\
\hline 29 & 昭和 4 & 別館増築・開業 & & & \\
\hline 30 & 昭和 5 & & & & \\
\hline 31 & 昭和 6 & & & 東館「コドモの国」增築・開業 & \\
\hline 32 & 昭和 7 & 新館增筑・開業 & & & \\
\hline 36 & 昭和 11 & & 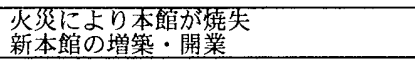 & 南館三階增築・開業 & \\
\hline 37 & 昭和 12 & 株式会社山形屋に改称 & & 二部鉄骨四階增栜・開業 & 百貨店法 \\
\hline$\frac{43}{45}$ & 照和 18 & 力霣厂 & 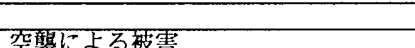 & 火苂による琵失 & \\
\hline 45 & 昭和 20 & 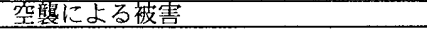 & 空㙰による被害 & 空襲による被害 & \\
\hline
\end{tabular}

1939 年までの創業期の主な日々の出来事が日誌的に記録されてい る資料（以下、「日誌」とする）もある。これらの西川秀男家文書 （以下、西川家文書とする）も活用した。

\section{2．百貨店の立地特性}

\section{(1) 天満屋}

天満屋の前身は、藩政期から岡山近郊の西大寺で営まれた呉服商 である。1896 年に合名会社伊原木呉服店を設立した。東京では三 越が 1893 年に越後屋を合名会社三井尅服店に改組しており、業界 内では比較的早い法人化であった。1901 年には天満屋呉服店に改 称した。

天満屋は、山陽鉄道を始めとして鉄道の結節点として商圈を拡大 しつつあった岡山への進出を目指し、1912 年 10 月、岡山市中之町 の店舗を買収して出店した。1922 年 5 月には、南隣の下之町に綿 布、洋反の分店を設けた。この分店では床をコンクリートにして、 座売りから立ち売りに改め、またガラス戸棚を導入した。1924 年 6 月に分店裹に新店舗の建設に着手、同年 12 月には本店をこの地 に移転し（図 1 )、西大寺の店を支店とした。その翌年 3 月には洋 風木造三階建ての新店舗で開業した。この新店舗が近代的な百貨店 としての出発となった。

1901 年に発表された岡山唱歌には、「上中下の三町に 続いて栄 紙屋町 西大寺町に橋本町 いずれも商売盛なり」という節がある。 上之町、中之町、下之町之連なるこの通りは、当時の岡山の中心商 業地であった。その中でも天満屋の発展によって、商店街の中心は それまでの上之町から下之町に移つたといわ扟ている注 6。この通り は 1924 年 5 月に自動車や荷馬車の通行が禁止され、歩行者中心の 「最も賑はしい通り注〕であった。1929 年に発行された観光案内 書湔×で推奖されている岡山駅を起終点とする市街の「遊覧順路」 においても、天満屋前の通りが含まれている（図 1)。なおこの通 りは1927年 2 月に認可された都市計画街路に指定されなかった注9。

1930 年 11 月に岡山で陸軍特別大演習が行われた。他の都市と同 様に、天皇一行を迎えるため市内の要所の整備が進められた。その
後の市街の様子は、「鶴見橋、城下停留所、岡山駅間は御覧の通り アスフアルトになりました。これも大演習の際の俄仕事です車鴐の 御通りになる所だけ鋪装したのです。…(略) …あちらこちらに十 三間幅の、人道車道を区別し、並樹を植並べた新道が出来て見ます と、昔大通りであつたこの目貫の町も、狭くて窮屈で、頭を圧へつ けられるやうで、よくもこれで済んで居たものだと感ぜられます。

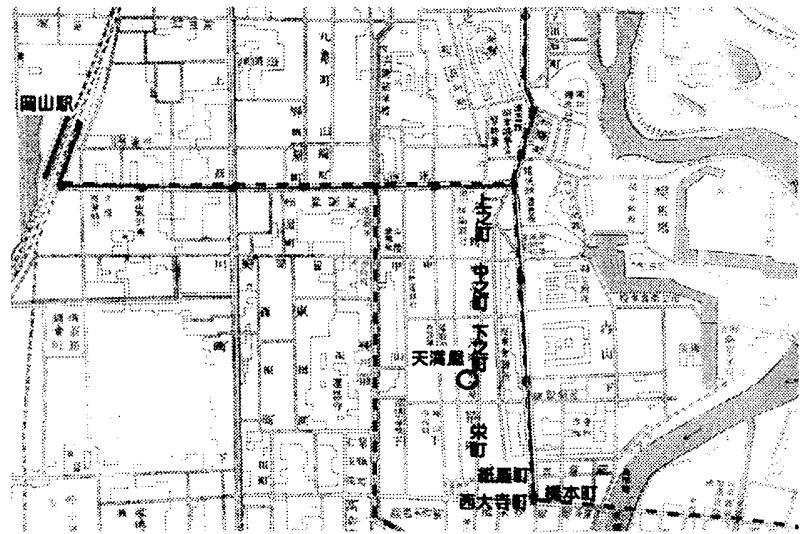

図 1 天満屋の立地と電気軌道ルート（電車通り）

(1920 年岡山市街図に天満屋と 1936 年時点の電気軌道ルートを記入)

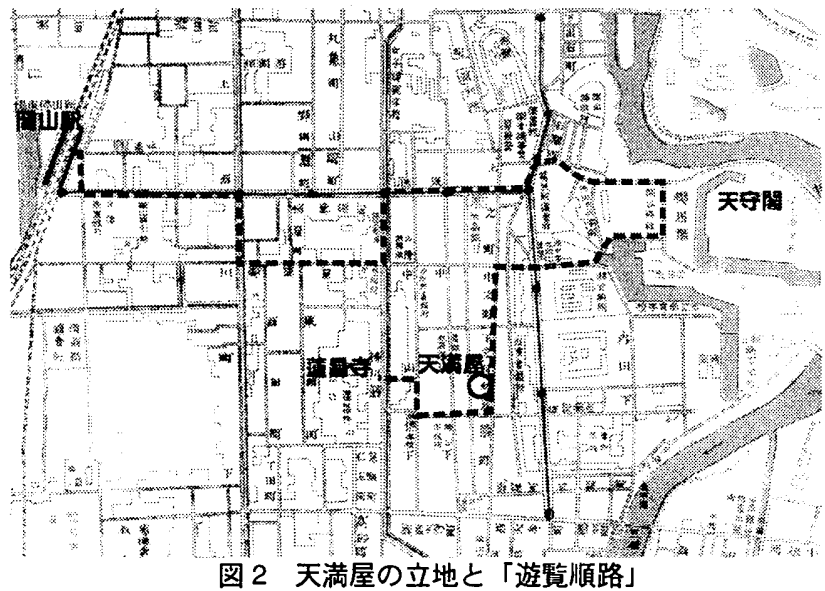

（1920 年岡山市街図に天満屋と連昌桨〜䦌山駅の遊覽順路を乨入） 
若し一二軒の本屋と天満屋とが無かつたならば、私は殆んどこの本 通りを通る事は無いでせう。泪10」と記されている。天満屋が立地 していた通りは、藩政期の「目报き通り」であり、明治以降も市内 の中心的繁華街であった。天満屋注近郊から岡山への進出に際し、 既に商店の連なる商業集積地に出店した。しかし市内の他の道路の 整備が進むと、この通りは相対的に「狭くて穿屈」な道路にみえる ようになったが、天満屋は百貨店として市民を強力に誘引している ことがわかる。

1934 年に金沢の商店主らが岡山を視察した報告汇 11 では、「…驛 近くに、唯一の商店街有り、上之町、中之町、下之町、…(略) … にして舗装されたる三間半位の道路の兩側に、五百餘りの商店軒を 並べ競うて顧客の吸収に餘念なし。静かなる電車通りより一歩入り て此の賑盛を見る、實に警くばかりに綺麗だ」と、この通りの賑わ いを表し、併せて天満屋についても、「相當の顧客を吸収」してい ると評している。

\section{（2）だるま屋}

福井の商家は藩政期、北陸街道に沿って発達した。明治時代に繁 華街として賑わっていたのは呉服町や本町である涪 12 。市街の東方 に立地した福井駅の開業（1896 年）当時は、駅前に百間堀があっ たので、市街の中心から東方の駅に向かうに恃大きく迁回しなけれ ばならなかった（図 3)。百間堀の南端が埋め立てられて、駅正面 から酉方向に延びる駅前通りが開通したのは、福井駅が開業してか ら 7 年後ひ 1903 年だった（図 4)。

この駅前通りには福井県庁舎が立地していた。この県庁舎は 1898 年に移転した師範学校の校舎を修綁して使用していた。校舎は 1877 年と 1890 年に建築さ扎たものである。老朽化に伴い新庁舎の建設 は検討さ扟ていたが、移転を前提としていた。旧藩主松平家に払い 下げられていた城址をその候補地として借り入れて交渉を進め、 1919 年無償貸与の契約が結ばれた。さっそく県会で県庁舎の新築
にかかる追加予算が審議された。総工費は的 115 万円、そのうち 約 111 万円を県債とし、現庁舎の敷地の売却代を約 90 万円として 県債の償還に充当する計画であった。県会での県当局による城址を 移転先とする理由では、土地が高燥であること、四周の眺望が雄大 であること、市の中心で交通の便が非常に良いことを挙げている注13。

県庁は 1922 年、城址本丸跡に新築・移転したが、その跡地約六 千坪の敷地の売却は進まなかった。県庁跡地の売却先探しを県知事 から嘱託としてその斡旋の依頼を受けていたのは、福井商業会議所 の書記長だった坪川信一であった。坪川は、それまでに面識のあっ た熊谷三太郎に相談に出かけている。熊谷は、熊谷組を興した人物 であり、当時、福井市会議長も務めていた。熊谷からは、六千坪を そのまま売るのではなく、小割りにするようアドバイスを受けた。

坪川は土地の存在価值を高めるとともに、その土地に市民の関心 を集めるために、納涼遊園地を企画した。このイベントで福井市民 の注目を集め、そのあとに忽然亡土地分割の売り出しを発表する段 取りだった。熊谷からのお墨付きをもらい、福井商業会議所主催で 1925 年、ひと夏だけの納涼遊園地が開催された。開催されると連 日の大賑わいとなった。その模様は地元紙注4に報じられている。 「市の中央に荒廃五千坪の空地を有する不体裁それを巧みに利用し て納涼と歓楽の巷にしようとの納涼遊園地」で、照明がふんだんに 取り入れられ、「光彩の海を泳ぐ人の波」「惜しげもなく使った電灯 に誰もが矓惑されて、佇む人が黒山のよう」というように大盛況で あった。新聞の見出しには「福井には出来過ぎた納涼遊園地」とあ った。

納涼遊園地はこうして盛況に終えた。その年の年度末、1926 年 3 月に改めて県庁跡地を区分して入札をすると、敷地の半分近くの 売却が決まった。莪信省や福井銀行などが買い手となった。しかし 中央部分約六百坪だけは売れなかった。坪川は壳却の経過を熊谷に 報告すると、熊谷から自分で買っても良いといら返事をもらった。 熊谷から、その土地の利用の仕方について辈ねられた坪川は、子供

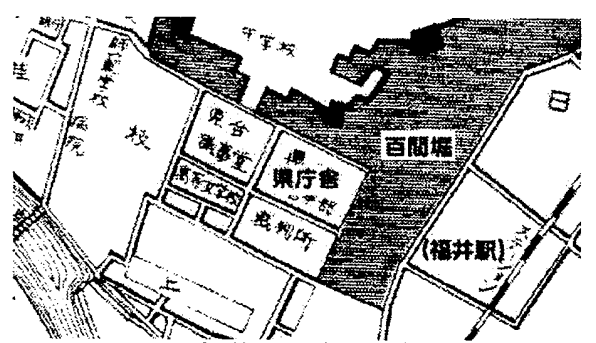

图 3 福井駅の建設予定地椡 15

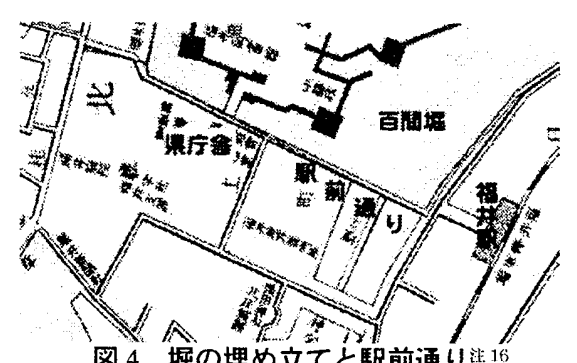

図 4 堀の埋め立て之駅前通り洁 16

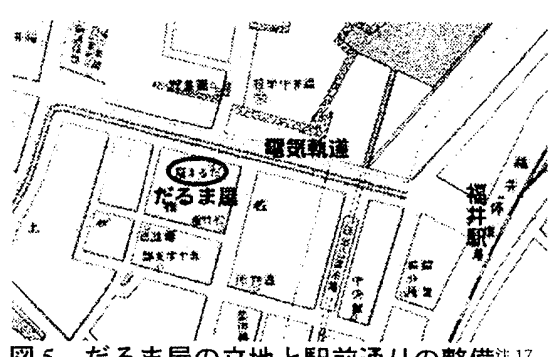

図 5 だるま屋の立地と駅前通りの整備让 17

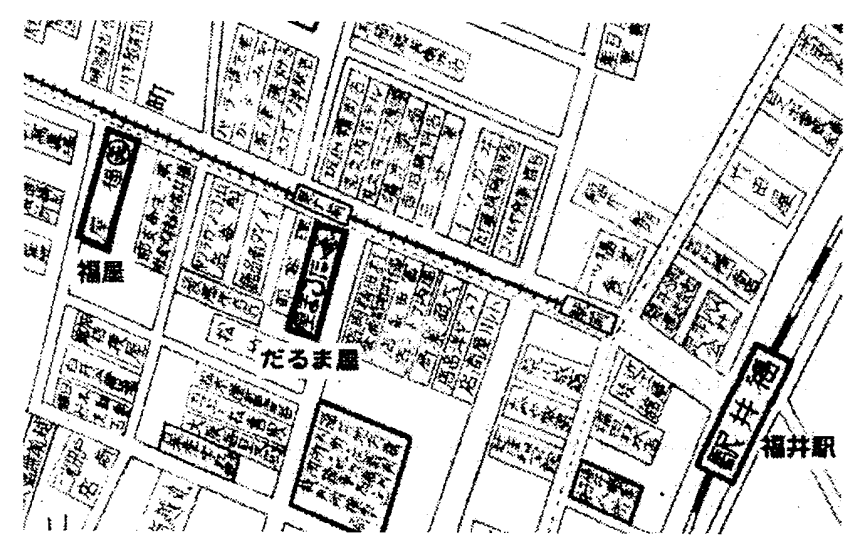

図 6 福井駅前通りの商店街形成泣 18

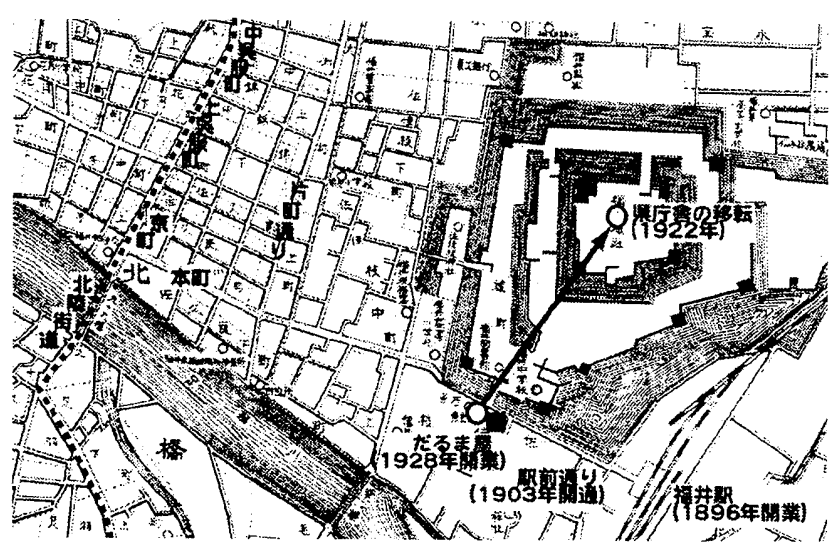

図 7 だるま屋の立地と市街地の関係 1 1 19 
のための教盖、娛楽、洋品販売を中心とした百貨店を自ら経営した いと申し出た。熊谷はその考えに共鳴し、土地、建物、運転資金、 あわせて三十七万円余りの資金を提供した注 20 。こうして坪川は県 庁跡地に 1928 年、だるま屋を創業した。福井市内にはそれまで勧 工場や公設市場があったが、いずれも異業種の小売業者が集まった 寄り合い型の店舗であった。百貨店としてはこのだるま屋が最初で あった。

1930 年の地元紙には、「福井の繁華にも大きな変遷が見られる、 そのかみ吳服町・京町辺の北陸街道が中心街だつたのが、鉄道の開 通後少しづつ淋れ、二、三年前までは片町通りが繁華に酔うてるた、 そ扎が最近では駅前通りに移り東から西へ進んだといは扎る世界文 明に反して、福井の繁華はかくして漸次西から東へ移つてきた注 ${ }^{21}$ と報じられた。夜になると人通りが途絶えた駅前通りも、ただるま 屋の電飾が不夜城のように明るく、閉店時間の夜十時まで人通りが 絶えなくなった。

また近くの堀は 1933 年頃から埋め立てられ、家屋が建ち並ぶよ うになった。1932 年に認可された都市計画街路では、だるま屋前 の駅前通りの幅員は $22 \mathrm{~m}$ で計画された注 22 。これは市内で最も広幅 員である。翌 1933 年は陸軍大演習のあった年であり、そ㣗に併せ て市内幹線道路や橋梁の整備が進んだ。福武電気鉄道が福井駅前ま で延伸し、だるま屋前の駅前通りに軌道が敷設され、同年 10 月に 開通した（図 5 )。駅前通りは舖装され、歩車分離により、随一の 目拔き通りとなった。

だるま屋に対抗して出店した百貨店である福屋の進出（1936 年 12 月開店）は、だるま屋の立地によって賑わいが生まれた駅前通 りの発展をさらに促し、市内第一の商店街が形成された注 23 (図 6 )。

\section{3. 建築計画と都市景観}

(1) 天満屋

\section{(1)百貨店建築としての開業}

1925 年 3 月に開店した天満屋の新築店舗は、十間四方の洋風木 造三階建て、延床面積約千 $\mathrm{m}^{2}$ であった。呉服太物、洋反物に加え、

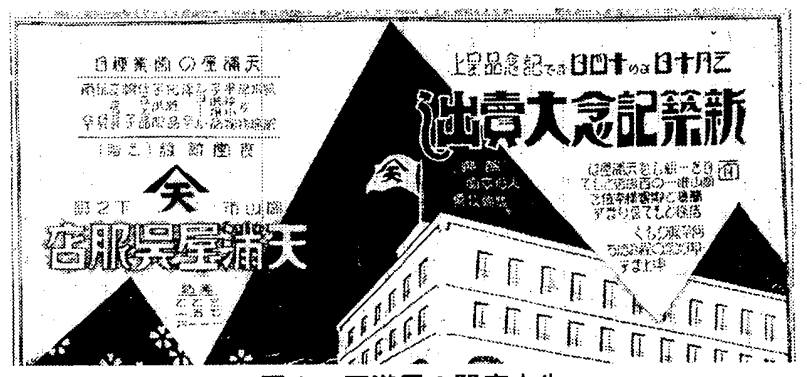

图 8 天満屋の開店広告

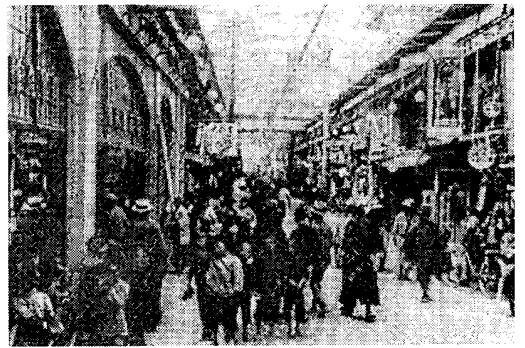

图 9 天满屋と前面道路

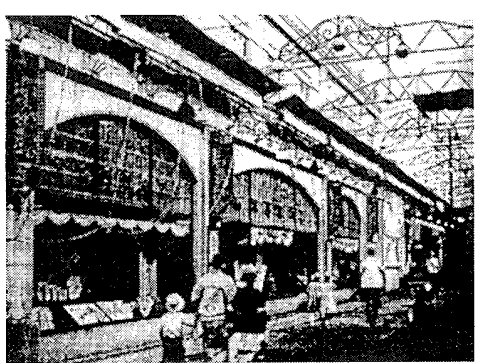

図 10 天満屋のショーウィンドー
洋品雑貨、子供服、化粧品、文具、おもちゃなどを取り揃えた。三 階には食堂があった。

開店にあたって、地元紙に「新築記念大売り出し」の 4 段抜きの 広告を載せている注 24 (図 8 )。広告の中では、仰ぎ見る三層の建物 の絵とともに、「面目を一新した天満屋は岡山唯一の百貨店として 簡易と御客様本意を信條として居ります」と記されている。新築に よる「面目の一新」と「岡山唯一の百貨店」の誕生について、新規 性、優位性、さらに「簡易」という大衆性を打ち出している。実際 には三層であるが、一階部分を図では省略し、仰ぎ見る構図によっ て高さを主張している。

開店日は陸軍記念日で、連隊では軍旗祭などがあり郊外からも人 出があった。例年の多くの人出にあわせた開店日であった。入店す る客の整理が追いつかず、入店の規制を行った。陳列ケースと販売 台を並べ、立ち売りの対面販売であった。開店時はまだ下足預かり 制度であり、靴を履いている客には鞉覆いを出し、通路に敷いたご ざの上を歩かせた。

新規開店の様子は新聞には報じられなかったが、天満屋は 3 月 16 日の地元紙に「御礼広告」を揭載した注 ${ }^{2 i}$ 。そこでは「過般新築記 念賣出開催中は賑々しく御光來賜はり有難く御禮申上候何分開店 早々且つは混雑の際何角と不行届の段謹で御詫申上候」と記されて いる。混雑時の対応への一種のお詫びであり、謙虚な姿勢を示して いる。新聞記事として報じられなかった分、来店していない読者に 対して盛況な様子を広報するという新聞広告の効果を活かしている。

\section{(2)増築の店舖とまち並み詈観}

1925 年の開業以来、隣接する土地の買収を進めるとともに、別 館（1926 年 10 月 20 日）、西館（1927 年 3 月 10 日）、北館（1927 年 5 月 5 月）と相次いで増築した（図 11）。

別館は鉄筋コンクリート造の三階建てで事務部門と従業員の食堂 や宿泊施設等を収容した。西館は本館に隣接して増築され、写真室

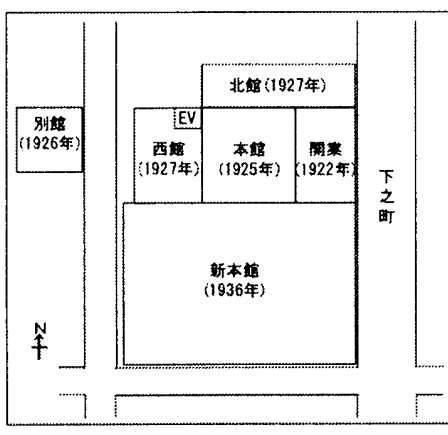

図 11 天满屋店舖の配罟見取図注 26

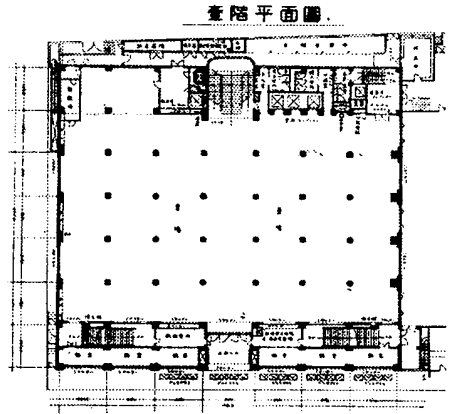

図 12 一階平面図（新本館）

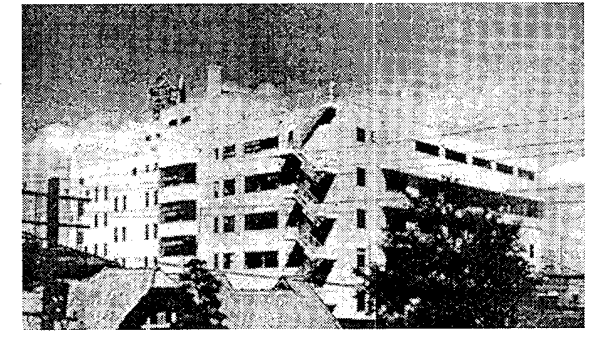

図 13 南西からの眺望（新本館） 
や理髪室などサービス部門を加えた。北館の開業時に、下足預かり 制度を廃止し、本館の屋上には庭園と展望台を設けた。

こうした増築の中で特に話題となったのはエレベータの導入であ った。1927 年の增築の際には、「天満屋のエレベーター 明五日か ら運轉開始」と題して增築落成披露の案内記事が掲載された注 27 。 増築にあわせて店内を大改造し、岡山市で最初の乗客用エレベー夕 を新設し、屋上に七十坪の屋上庭園と二十坪の展望台を設けて、「理 想的のデハート」にしたと報じられた。

さらに買収した郵便局跡地の南側の空地で 1935 年 2 月、新本館 の工事が始まった。1935 年発行の岡山の観光案内書には、天満屋 について「中國一の大デバートで一日數萬の顧客を吞吐してるる」 と紹介し、新館目下增築中として完成予想図を揭載している注 28 。 なお 1934 年 9 月の室戸台風により岡山市内は市街地も浸水し、天 満屋の店舗も 1 階売り場が浸水した。この経験から、新本館は 1 階 の床の高さを高くするために設計変更がされている注 $29 。$

また新本館の工事も進み、四階までできていた工事最中の 1936 年 3 月 11 日に、三階建ての木造本館が全焼した。午前七時頃、三 階の食堂付近から出火し、「何分同所は岡山目貫きの商店街で大小 建物が並んでおり注 30 小、北側に隣接する派出所、商店や写真館など に延焼した。火災当日は地元紙が号外を出して報じている。所轄の 警察署長は、高首建築物の防火施設には学ぶべきものがあると語つ ている汒 31 。天満屋の経営者は、火災に弱い木造を目の当たりにし て、工事中の新本館が鉄筋コンクリート造であることの妥当性を再 認識したに違いない。

新本館は、1936 年 8 月 31 日に竣工した。9 月 30 日に落成式、 開業は翌 10 月 1 日である。開業日当日の地元紙には見開き二面に 渡った紹介記事と企業広告が掲載されている注 32 。その中では、「岡 山名所の天満屋新館が落成」し「岡山商店街の中樞部に屹立するク リーム色の湩酒な現代日本式、高楼六層の威容は縣下高層建築史上 に初頁を飾る」として報じられた。塔屋は、「トッブにヤマテンの 社旗を翻へし夜はテンヤマのネオンサインが岡山の街何処からで も」眺められた。高さは「實に地上百二十三尺餘り、ここからは岡 山市内は一眺に納められ、遠く児島の海も眼の下に集ま」ってくる と紹介されている往 3 。建物の高さが強調されている。この新本館 は、地下一階、地上六階、エレベータのほか、冷暖房装置も導入さ 㧈た。五階には七百名収容の大食堂、屋上には「子供の国」がつく られた。東側正面の軒高はスケートリンクの切妻を除いて 90.5 尺 (約 $27 \mathrm{~m}$ )、塔屋上端までは 123.5 尺（約 $37 \mathrm{~m}$ ) であった。一階 の通りに面して、正面入口の左右に飾り空（ショーウインドー）が あり、その床は桜の寄せ木貼りであった注㣙。

先述のように天満屋の立地していた通りは、封建時代の「目抜き
通り」で、その道路幅員は狭いままだった。そのため、記事では建 物の高さが強調されたが、この通りからは店舗の高層部を含む外観 を一望することはできなかった。高層部を表すには別な角度からの 写真にならざるをえなかった（図 13）。本館開業後の写真（図 9、 10）をみると、この通りには「日覆い」が設けられていたことがわ かる。この「日覆い」は、商店街の共同施設で、構造は鉄製の細い 支柱と析であった。その上部に、必要に応じて布製の覆いを道路全 面に渡した、現在のアーケードの原型である注3. 高層化が図られ ても、この日覆いが渡されたらなおさら、通りからはその全容を認 識することはできない。通りを歩く人々は、道路に面したショーウ インドーを通して百貨店の存在を意識した。

\section{（2）だるま屋}

\section{(1)創業店哺の建築と開業前後}

だるま屋は 1927 年 12 月、店舗の基礎工事に着手している。そ の工事の光景は人々の衆目を集めた。「昭和三年のまだ淺い三月初 め、舊縣廳舎跡の廣場の一角に作られた五百坪ばかりの板圍ひの街 路に面した右の端に「だ」の字が一つ大きく浮き出した。「何だら う?」人々の眼は皆一様に其の「だ」の字に囚はれた。…(中略) …噂は早くも街から街へと傳はつて行き、人々は不思議な好奇心に 唆られてるた。と其の翌日「だ」の字の次へ「る」の字が又現はれ た。次の日には「ま」の字、その次の日には「屋」の字が出て、そ れは「だるま屋建築敷地」であることが始めて吞み込めた。だるま 屋と云ふ名稱は斯うしてまだ建築が出来ない前から市民のみならず 廣く縣下の方々へ知れ渡つてしまつたのである注 $36 」 と$ 伝えられて いる。

その当時、福井駅の駅舎も拡張工事がされていた。それにあわせ るように、だるま屋も新築工事が進んだ。「きのふ迄の野原のやう であつたあの廣場に今盛んに建築を急いでるるのは「だるま屋」で
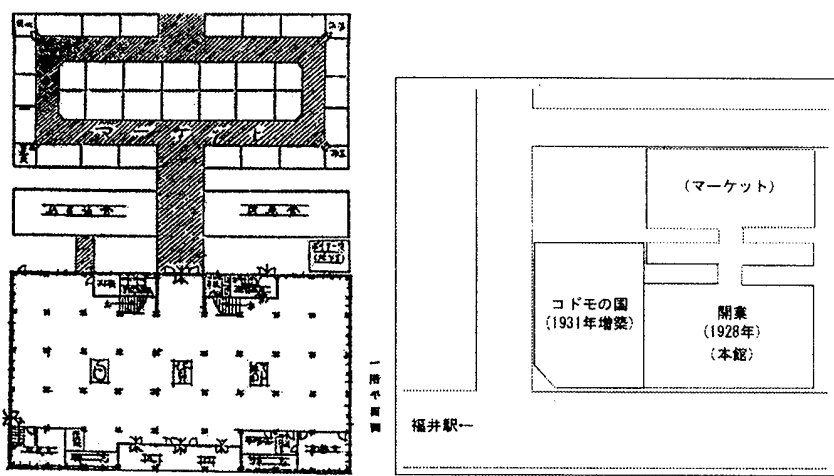

図 14 だるま屋の一階平面図 図 15 だるま屋店舗の配置見取図

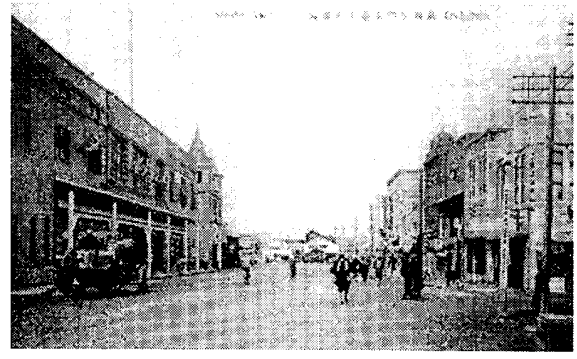

図 16 だるま屋と駅前通り

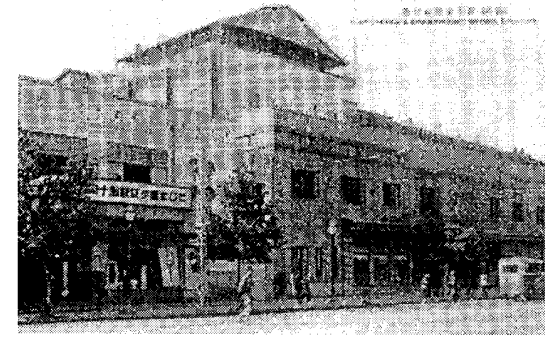

図 17 増築後のだるま屋

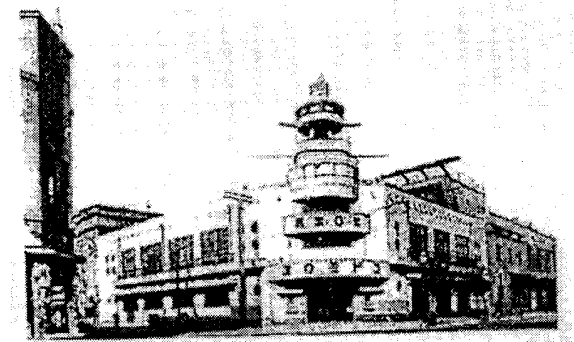

图 18 「コドモの国」増築 
何がさて福井の玄關通りに無くてならない立派な建築だ」と、だる ま屋の建築中の写真を添えて地元紙に報じられている注 37 。このよ うに建築工事中から、新たな店舗の出現に対する期待があった。

開店当日は、地元紙の第一面の右下に紙面の $1 / 4$ ほどのスペー スに、特売部売り出し品として特製コナ石喃と、コドモ百货部の二 つの広告宣伝を揭載している注 38 。同じ新聞の第四面には記事とし て「だるま屋」の開店が写真とともに紹介された。

創業当時の店舗は、木造二階建て、間口 25 間、奥行 15 間の本 館のほかに、南側には平屋建ての貸店鋪マーケットがあった注 39 。 このマーケットの出店者を建築中の 5 月に賃貸市場として募集した 泾”。市内小売業者との共存という配慮は、坪川自身が福井商業会 議所の書記長という立場であったことと無関係ではないであろう。 開店当時のマ一ケットには八百屋、肉屋、洋服雑貨店など 25 店が 連なっていた注 41 。マーケットはコの字形に通路が設けてあり、通 路に面して両側に問口 2 間くらいの店が並んでいた（図 14）。常時 20 前後の店鋪が入居し、正札販売、現金販売、商品の価格は市価 以下とするなどの共通の営業方釙により、相当の利用者があった。

だるま屋は 1928 年 7 月 6 日の大安に開業し、初日は大盛況だっ た。一万人を越える客足で注 42、屋上バルコニーの「子供の遊び場」 は数百人もの子供で賑わった。マーケットも「大入満員で往き来ふ にも支障を感ずる」ほどだった注 43 。比較的、郊外の郡部からの客 が多かったらしい。あまりの混雑さに、警察当局からの注意があり、

表 2 だるま屋の来店客数の推移

\begin{tabular}{|c|c|c|c|c|}
\hline & 期間 & 営業 & $\begin{array}{l}\text { 客数/ } \\
\text { (人) }\end{array}$ & 䚚考 \\
\hline 1928年7月 & 〜 11月 & 145 & 2,606 & 開店 \\
\hline 1928 年 12 月 & 〜 1929年 6 月 & 210 & 2,343 & \\
\hline 1929 年 12 月 & 〜 1930年11月 & 361 & 3,061 & \\
\hline 1930 年 12 月 & 〜 1931年11月 & 363 & 3,505 & $\begin{array}{l}1 \text { 月コドモの国 } \\
11 \text { 月少女歌劇 }\end{array}$ \\
\hline 1931年12月 & 〜 1932年11月 & 363 & 4,056 & \\
\hline 1932 年 12 月 & 〜 1933年 11月 & 360 & 5,423 & \\
\hline 1933 年 12 月 & 〜 1934年11月 & 351 & 5,872 & \\
\hline 1934 年 12 月 & 〜 1935年 11 月 & 352 & 6,137 & \\
\hline
\end{tabular}

注：「日誌」西川家文書、福井県文書館より作成（記録は 1935 年 11 月まで）
閉店予定時間を待たずに店を閉じざるをえなかった。その時には店 舖前にはまだ一千人あまりの客がいたという社 4 。開店二日目も、 開店時間前にすでに数百人が玄関前に押し掛けていた注 4 。

\section{(2)「コドモの国」の増築}

開業三年目の 1931 年、本館に付属して「コドモの国」が増築さ れた。1 月 2 日に開館したが、冬季には子供の遊び場がなくなる福

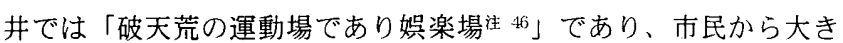
な期待を寄せられていた。二階建てで、各階二百数十坪あり、遊具 施設や運動用品が多数用意されていた。

さらに「コドモの国」を一部改造し、定員 180 席の舞台付きの ホールがつくられた。そして常設の少女歌劇を結成した。1931 年 11 月の初演から 1936 年 8 月 1 日の終演まで、8 月を除いて毎月演

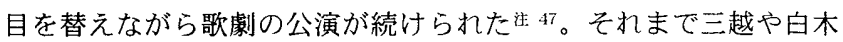
屋などの百貨店では、少年あるいは少女音楽隊を結成していた。一 方、少女歌劇は宝塚や松竹などがあり、戦前に全国で 20 以上あっ た注 48 。店主の坪川は関西で盛んだった少女歌劇を取り入れ、コド モの国というレジャー施設に付随する劇場の形式など、宝塚の影響 を強く受けている。しかし百貨店が主催する歌劇で、かつすべての 歌劇部員が店員であるというだるま屋少女歌劇は全国でも特異な存 在であった。なお坪川は松竹少女歌劇のファンであったらしい社49。 1935 年に公会堂ができるまで、市内には適当な舞台付きの集会施 設がなかったため、だるま屋のホールが集会や展覧会などの会場と しても利用された。

このようにだるま屋は単なる営利目的の百貨店経営ではなく、坪 川は文化や教育にも軸足を置いた運営を重視した。資金を提供した 熊谷はこの百貨店の経営が心配の種であったらしい。口癖のように 家族にもらしていた注 50 。ことあるごとに店の様子を見に出かけ、 競合する福屋百貨店の開店日には、夫人に様子を見に行かせたりし ていた。しかし坪川は創業後も相次ぎ増築を進め、積極的な経営姿

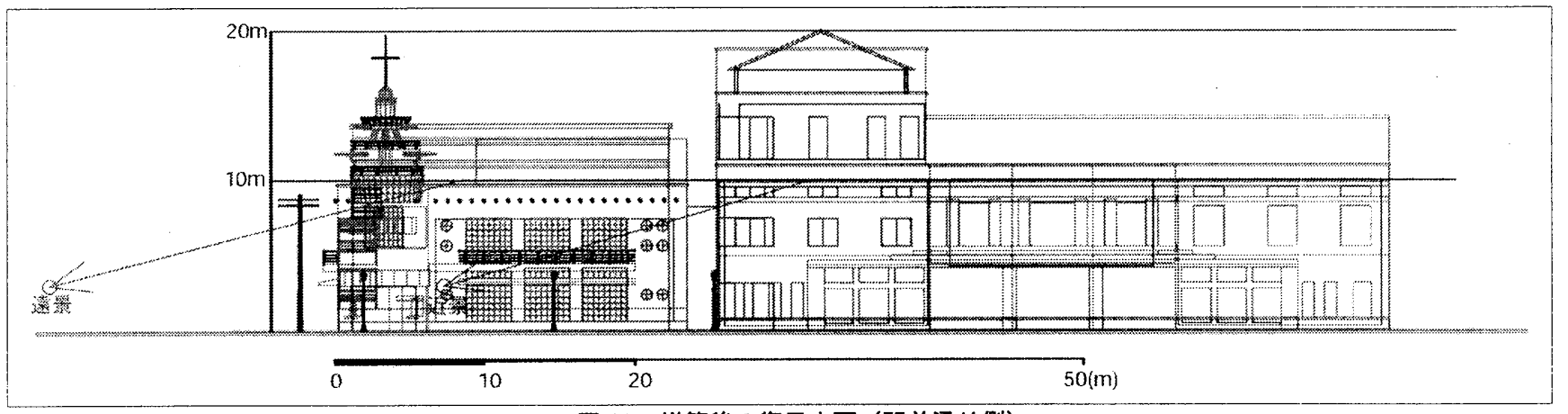

图 19 增築後の復元立面（駅前通り側）

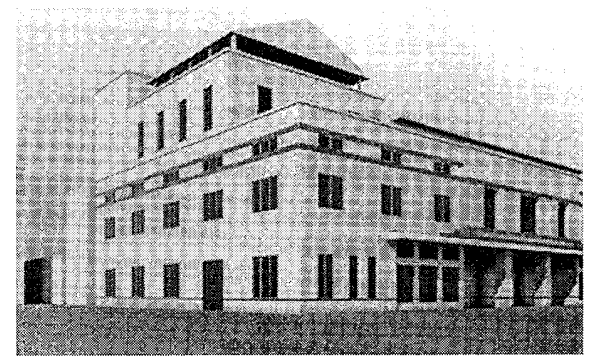

図 20 創業時の復元（近景）

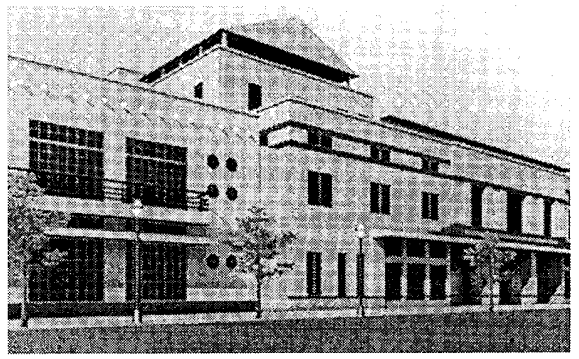

図 21 増築後の復元（近量）

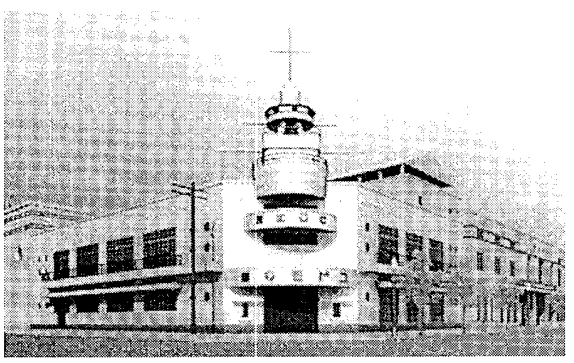

図 22 増築後の復元（遠景） 
勢を堅持した。創業以来、景気に左右されず来店客数は増加し（表 2)、黒字を重ねていたことは、それだけ市民の支持を得ていたこ とを実証している。当時は人口十万人が百貨店の成立の目安とされ ていだが、人口六万人の福井で成功しただるま屋は、その意味 でも業界内で注目された。坪川の主義である「教育の商業化を標榜 $し て 、$ 理想的な百貨店經営を試み全國百貨店中に異彩を放って」い たし、「内外店員のサービスが實に行届いた點は、全國業界の範と するに足るものである」と言われていた淮的。

\section{(3まち並み景観}

駅前通りに面して正面入口のあっただるま屋の創業店舗のファサ ードには特に特徴はみられない（図 14、16）。これまでに確認で きた平面図及び写真から、既稿注 年に開業した「コドモの国」增築後の外観についてC Gによる復元 を試みた（図 19〜22）。なお図 21 と図 17 は同じ構図であり、図 20 は図 21 と同じ視点場から見た創業時の外観（近景）である。図 22 は増築後の遠景である。

「コドモの国」は角地に增築され、入口はその角に設けられた（図 18、22)。その上層部に加えられた展望塔は、白木屋や山形屋など でも採り入れられた手法であり、角地建築の商業施設の正面性を象 徵している。しかしだるま屋のそ㧈は他の百貨店とは異なり、建築 的な一体感は乏しく、上部に付け加えら㧈た装置といった感がある。

福井駅から歩いてこのだるま屋に向かった当時の景観は次のよう に記されている。「驛を出ると眼前に展けた福井の第一印象は、田 舎とは思へない街の清新さで、だるま屋は、この驛前通り、福井城 趾の石垣と相對し、武家盛んなりし頃を嘲笑ふが如く、時代の新し い装ひを誇り顔に建つてめます。間口三十九間、奥行三十間、外観 二層、内部三層、延坪一千五百坪、大都市のデバートに比ぶれば物 の數なら貄物であるとしても、市の大きさ住宅の數に比べれば、 東京、大阪の大百貨店よりも、より大きい存在であるのです。注 $54 」$ これは、大都市の百貨店では赤字で閉鎖しているような不景気にあ って、人口わずか六万人の都市で大繁盛しているとして、だるま屋 を紹介している『主婦之友』に揭載された記事である。福井城址の 向かいにある近代的な百貨店を対照的に捉えている。

1935 年にだるま屋を訪れた立教大学の伊藤重治郎教授は、「驛を 出ると三町と走らないのに往く手に當つて巍然と答えた建物が滿館 電光のイルミネーションを煌々と輝かして居た。映畫館にしては大 きすぎる、劇場にしちやあ何となく様子が違ふが、と思ひながら近 づくと、何とそれが既にわが目指すだるま屋であつたのである。斯 んな市の取つ掛り、向側は昔の城の石垣の殘つて居る、言はぐまだ 郊外氣分の所に百貨店があらうとは、實は一寸意外であつた注 ${ }^{55} 」$

と、率直な印象を述べている。

やはり一般的イメージの百貨店、おそらく大都市の百貨店と比べ、 百貨店らしくない建物であること、かつ立地が城址の石垣に近い場 所であることに、とまどいが感じられている。

さらに続けて、「建物その物からして近來大都會に出來る百貨店 が華麗を競ふ所謂殿堂であるのと對照すると、この建物は先づ小學 校程度で、サッハリして入り易く親しみ易いもの」であり、店内の 気分が学校の創立記念日のバザーを連想させるなど、だるま屋百貨 店が「ピンから切まで、凡そ『百貨店』といふ概念とは違つた往き
方の事業団」として、百貨店という既成概念に当てはまらない存在 であると指摘している。

だるま屋の規模は決して大きくはなく、また高層でもない。した がって他の大都市の百貨店のようなまち並みへの威圧感はない。同 時代的記述にもあるように、百貨店建築としては異質であり、親近 感のある建物であった。それが市民に受け入れられた素地の一つに なったとみられる。

\section{4. 結論と考察}

本稿では天満屋とだるま屋の開業期の立地特性やまち並みにおけ る景観の実態について明らかにした。既稿で明らかにした山形屋も 対照すると、これら三百貨店から、六大都市以外の地方都市にも百 貨店が誕生した萌芽期から昭和に入ってからの後発の百貨店への展 開をみることができる。

山形屋と天満屋の経営母体をみると、他の大都市の百貨店と同様 に江戸時代の吳服店にまで遡る。ただし立地の経緯をみると両者は 異なる。山形屋は従来からの立地場所を拠点とし、軌道ルートを誘 致することで商業の中心となることに成功した。天満屋は、藩政期 からの商業集積地である現在地に近郊から進出した。また前面道路 の拡幅もなく、軌道ルートからもはずれているが、市内の中心商業 地を継承した。一方、昭和になって創業しただるま屋はまったくの 新たな開業であり、しかも商売の素人が百貨店の経営に乗り出した。 開業した場所は、駅前通りの福井県庁舎の跡地であり、出店計画時 は閑散とした場所であった。しかしだるま屋の開店と駅前通りの軌 道敷設を伴う整備によって繁華街へと発展することになった。

山形屋は高層大規模な建築として、まち並夕に対する圧倒的な存 在感があり、かつ角地に高塔を設けた建築としての象徵性を有し、 大都市の既存の百貨店の影響を強く受けている。天満屋は前面道路 の幅員が狭く、また日覆いがあるため、高層建築を見上げる視線を 確保できなかった。人通りの多い通りに面したショーウインドーに よって近代的な景観を表現し、誘客が図られた。だるま屋は低層の 「百貨店らしくない」建築であり、地元小売商との共存の志向、歌 劇の導入や子供重視の姿勢などの独特な理念によって、地域に密着 した経営が採られた。ただし天満屋とだるま屋は、ぞれぞれ増築に よって角地に立地することなり、二方向からの誘客を可能とした。 そしてだるま屋は増築によって角地店舗の象徵性を付与した。

このように三者とも、経営や立地の経緯は異なるが、いずれも市 民の支持を得て、持続的な経営と増築などの積極的な投資に結びつ いた。地方の百貨店の萌芽期にある山形屋は先行する大都市の百貨 店の影響を強く受けたが、それ以降に開業した天満屋やだるま屋で は、そうした成功体験をそのまま採用するのではなく、独自色が強 かった。

\section{付記}

本研究は、大林都市研究振興財団から研究助成を受けた。記して謝 意を表したい。

\section{菘考文献}

1) 天満屋 : 天満屋百五十年史、天満屋、昭和 54 年

2) 本館新築工事概要、天满屋、発行年不明（内容は昭和 11 年の新築工事の こと) 
3）天満屋：記念、天満屋、昭和 3 年

4) 岡铱斗: 天満屋の歴史、岡山新聞社、昭和 28 年

5）滕时村雨：だるま屋店主坪川信一の偉業、丁酉社、昭和 13 年

6) 曲川秀男家文畫、福井県文書館藏

7) 野中勝利：鹿览島・山形屋の開業時の立地と景観一地方都市における近代 白貨店に関する研究一、日本建築学会計画系論文集 No.611、2007 年、 pp159-166

\section{図版出典}

図 1 及び図 2「岡山市街全図」(筆者藏) 部分・D部加筆

汶 8 山陽新聞、大正 14 年 3 月 7 日

四 9 新聞記事と写真で見る世相おかやま [昭和戦前明治大正編]、山陽新聞 社出版局、平成 2 年、 $\mathrm{p} 221$

忷 10 参考文献 3）図 12 参考文献 2)

汹 13 大时本百貨拈帖、百貨店新聞补、昭和 12 年、所収

脳 14 参考文献 6) 図 16 及び図 17 絵はがき(筆者藏) 図 18 参考文献 6)

注

注1) 参考文献 7)

注2) だるま屋は、1980 年に「だるま屋西武」、2006 年 2 月 26 日に「福井 西武」となっている。

注3) 参考文献 1) 4)

注4) 参考文献 5)

注5）福井県文書館：文書館だより、第 3 号、福井県文書館、2004 年、p6

注:6)阙山市百年史編さ九委員会編：岡山抒百年史上巻、岡山市、平成元年、 p594

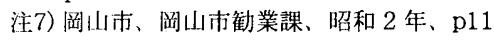

注8) 宇垣武治 : 岡山の遊覧、細謹舎、昭和 4 年

注9）「昭和二年公文雑箱」巻 31、国立.公文書館所藏

注10) 榊亀吉: 閑空臥遊、松本米次郎 (私家版)、昭和 7 年、 17

注11）商店員の先進都市商業視察報告、金澤商工會議所月報、第 44 巻第 5 号、昭和 9 年、 $\mathrm{pp} 10-16$

注:12) 明治 7 年の町名の整理統合で、呉服町と本町は、それぞれ大和上町 · 大和下町、昭手上町になり一-般の市街図にもその町名になっているが、 一般市民の日常生活にまでは浸透せず、藩政時代の町名が多く使用され ていた（福井市：福井市史資料編別巻絵図・地図、平成元年、p208）。

注13）福俦県議会史編さん委員会編：福井県議会史第二巻、福井県議会、昭 和 49 年、 pp1124-1126、pp1168-1171

注14) 福料新聞、大正 14 年 7 月 6 日

注15）「福井市全図」明治 27 年（福井市史編さん委員会編：新修福井市史、 附録市街地図、福井南、昭和 51 年、所収) ・部分・部加筆

注16）「市区改正福井市街地図」明治 41 年（筆者蔵）・部分・部加筆

注17）「福井市街全図」昭和 8 年（福井市史資料編別巻絵図・地図、福井市、 平成元年、所収) 部分 - 一部加筆

注:18）「大日本職業別明細図・福井市」昭和 15 年 (筆者蔵) ・部分・一部加 筆

注:19）福扑书街地図」明治 42 年（福井市史編さん委員会編：新修福井市史、 附録市街地図、福井市、昭和 51 年、所収) - 部分・ 一部加筆
注20）あゆみ一福井商工会議所八十年史一、福井商士会議所八十年史編纂委 員会、昭和 39 年、pp142-143

注21）大阪朝日新聞福井版、昭和 5 年 1 月 9 日（福井市史資料編 11 近現代 二、福井市、平成 6 年、pp951-952)

注22）「昭和七年公文雑篹」巻 45、国立公文菁館所龆

注23）福井市役所編：稿本福井市史上巻、福井市役所、昭和 16 年、p805

注24）山陽新報、大正 14 年 3 月 7 日、9 日

注25）山陽新報、大正 14 年 3 月 16 日

注26）参考文献 1)、p51 より作成

注27）山陽新報、昭和 2 年 5 月 4 日

注28）観光の岡山、岡山宣傅社、昭和 10 年、瓔なし

注29) 参考文献(4)、p64

注30）山陽新報、昭和 11 年 3 月 11 日付号外

注31) 山陽新報、昭和 11 年 3 月 12 日

注32) 山陽新報、昭和 11 年 10 月 1 日

注33）山陽新報、昭和 11 年 10 月 1 日

注34）参考文献 2)、p3

注35) 辻原万規彦、藤岡里圭：アーケードの原型としての日蕧いに関する研 究、日本建築学会計画系論文集 第 596 号、2005 年、pp85-92

注36）参考文献 5)、p3

注37) 福井新聞、昭和 3 年 4 月 3 日

注38) 福井新聞、昭和 3 年 7 月 6 日

注39）西川家文書、福井県文書館所蔵

注40) 福井新聞（昭和 3 年 5 月 13 日）に「市場賃貸広告」を掲載し、営業 種目は米穀類ほか 31 種、申し込み期日は 5 月 15 日限りという条件で あった。

注41) 福井新聞、昭和 3 年 7 月 5 日

注42) 福井新聞、昭和 3 年 7 月 8 日

注43) 福井新聞、昭和 3 年 7 月 7 日

注44）坪川信一：思い出の数々、熊谷三太郎伝記編纂室編：熊谷 $:$ 太郎、熊 谷三太郎伝記編篹室、昭和 32 年、pp171-221

注45) 福井新聞、昭和 3 年 7 月 8 日

注46) 福井新聞、昭和 6 年 1 月 1 日

注47）「だるま屋少女歌劇ブログラム」高田富家文書、福井県文書館所藏

注48）倉橋滋樹／辻則彦: 少女歌劇の光芒、青污社、2005 年、p7

注49) わがまち福井、福井市・福井书教育委員会、平成 2 年、p90

注50) 熊谷太三郎：父の思い出、前掲 : 熊谷二太郎、pp115-116

注51）伊藤重治郎：百貨店の䞶势、講演と沿革、早稻田大學廣告研究會、昭 和 8 年、 pp39-62

注52）昭和十二年版日本百貨店総覧、百貨店新聞社、昭和 11 年、 pp174-175 注53) 参考文献 7)

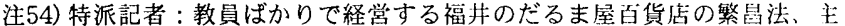
婦之友、主婦之友社、昭和 8 年 1 月号、pp356-365

注55) 伊藤重治郎：特異の経営で当つただるま屋の繁栄振り、現代、大日本 雄弁会講談社、昭和 10 年 7 月号、pp520-525

（2006年12月 6 日原稿受理，2007年 6 月 1 日採用決定 